\title{
Konservasi Koleksi Negatif Kaca
}

\author{
Mananti Amperawan Marpaung \\ Direktorat Pelestarian Cagar Budaya dan Permuseuman \\ Email : ma_marpaung@yahoo.co.id
}

\begin{abstract}
Abstrak: Negatif kaca merupakan dokumen kuno yang sangat berharga dan dimiliki oleh Direktorat Pelestarian Cagar Budaya dan Permuseuman yang berasal dari masa Pemerintahan Kolonial Belanda. Nilai penting negatif kaca adalah sebagai data dokumentasi mengenai penemuan awal peninggalan purbakala khususnya di Indonesia. Gambaran objek yang dihasilkan negatif kaca juga yang digunakan sebagai gambar atau ilustrasi pada penerbitan di masa lalu, salah satunya untuk penerbitan majalah Bataviaasch Genotschaap.

Dokumentasi tersebut menunjukkan adanya aktivitas Kantor Dinas Purbakala pada masa kolonial Belanda (Oidheidkundige Dienst). Kantor Dinas Purbakala tersebut berperan dalam menyebarkan dan mendokumentasikan peninggalan purbakala yang ada di Indonesia khususnya wilayah-wilayah yang menjadi pusat pemerintahan dan perdagangan Pemerintah Kolonial Belanda.

Penanganan konservasi negatif kaca di antaranya dilakukan dengan cara, pengambilan negatif kaca dari kotak penyimpnan yang terbuat dari kayu, pendataan ulang negatif kaca, pembersihan kering, pembersihan basah, digitalisasi database dengan Scanning negatif kaca dan pengembalian negatif kaca ke kotak penyimpanan.
\end{abstract}

Kata Kunci : Negatif kaca, konservasi, dokumentasi

\begin{abstract}
Glass negative is an important old document owned by Directorate for Cultural Heritage Preservation and Museum, because it came from Dutch East Indies period. The photos are documentation from early archaeological discovery. There was some glass negatives used as an image or illustration for old publication, such as magazines published by Bataviaasch Genotschaap.

The documentation shows that the activities of Archaeological Office in Dutch East Indies period (Oidheidkundige Dienst) in spreading and documenting archaeological heritage in Indonesia especially in the regions that become center for government and trading.

The measure for glass negative is performed by taking glass negative from wooden storage box, re-registration of glass negative, dry cleaning, wet cleaning, digitalization database by glass negative scanner and putting back glass negative to storage box.
\end{abstract}

Keywords: Glass negative, conservation, documentation

\section{A. Pendahuluan}

Negatif kaca adalah salah satu dari sekian dokumen kepurbakalaan yang di miliki Direktorat Pelestarian Cagar Budaya dan Permuseuman, Direktorat Jenderal Kebudayaan, Kementerian Pendidikan dan Kebudayaan yang saat ini di simpan di ruang penyimpanan milik Direktorat Pelestarian Cagar Budaya dan Permuseuman yaitu di Gedung bekas SMPN 35, Kompleks Galeri Nasional, Jalan Medan Merdeka Timur, Jakarta Pusat. Negatif-negatif kaca tersebut disimpan dalam salah satu ruangan bekas sekolah SMP Negeri, yang berada di lantai dua, ruangan tersebut merupakan ruangan khusus yang dipersiapkan untuk penyimpanan koleksi negatif kaca.

Negatif kaca tersebut mempunyai nilai penting karena merupakan bukti awal sejarah pendokumentasian peninggalan kepurbakalaan di Indonesia. Dari foto-foto yang terekam dapat diketahui bahwa dokumen tersebut berasal dari masa-masa awal penemuan peninggalan purbakala pada masa pemerintahan kolonial Belanda.

Negatif kaca ini sekarang kondisinya terus mengalami proses kerusakan sesuai dengan perjalanan waktu, hal ini disebabkan oleh faktor internal (kualitas bahan) dan faktor eksternal (faktor lingkungan), serta faktor umur yang sudah ratusan tahun.

Foto negatif berbahan dasar kaca disimpan dalam kotak kayu yang posisinya berdiri. Satu kotak memuat lebih kurang 20 negatif kaca. Sebagian negatif kaca kondisinya retak atau pecah, selain itu ada juga yang lapisan emulsinya terangkat sehingga mengakibatkan sebagian gambar hilang. Ada juga yang sebagian lempeng negatif kaca 


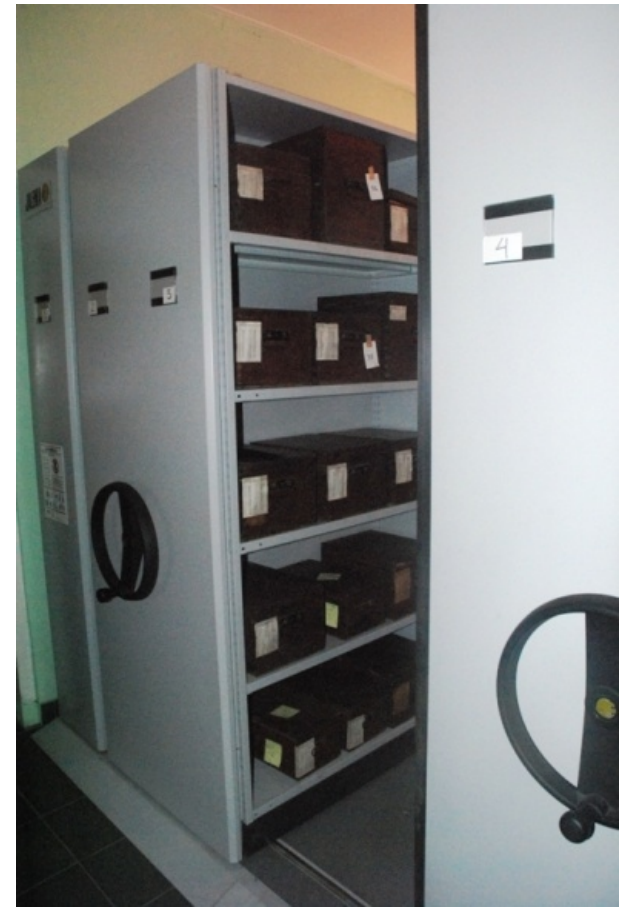

Foto 1. Tempat penyimpanan negative kaca pada Direktorat Pelestarian Cagar Budaya dan Permuseuman.

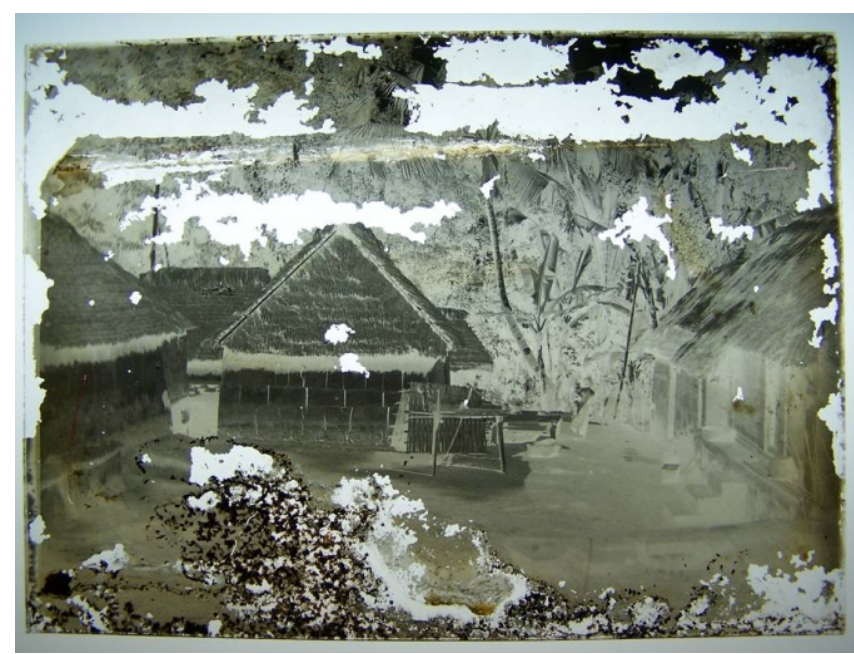

Foto 2. Kerusakan yang terjadi pada negatif kaca.

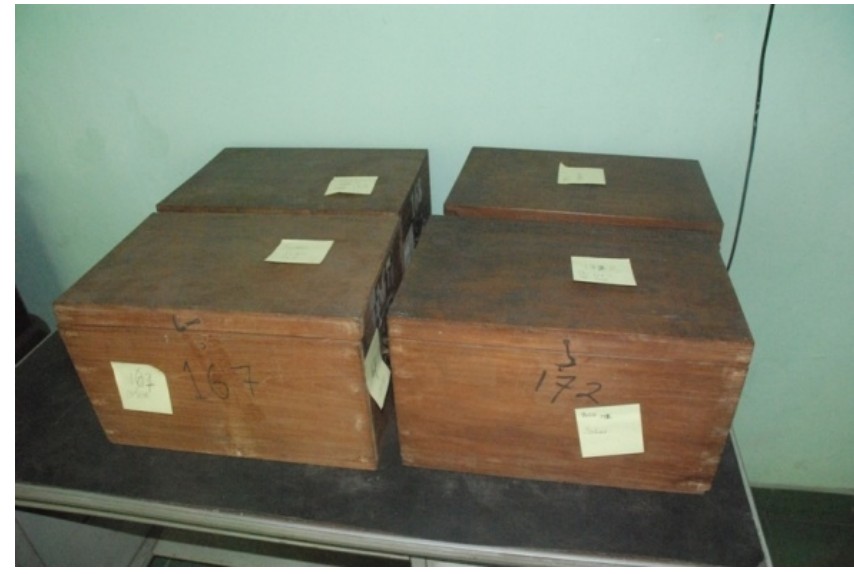

Foto 3. Kondisi kotak penyimpanan negatif kaca.

dijumpai noda-noda putih, ada pula yang bagian tepi kaca mulai pecah sebagian.
Pada umumnya kotak kayu dalam kondisi baik, namun ada sebagian yang perlu diperbaiki seperti sambungan papan merenggang dan retak, serta kait dan bagian engsel berkarat, sehingga tidak dapat ditutup dengan rapat. Saat ini terdapat 306 kotak kayu jati dengan berbagai ukuran.

Sebagai upaya untuk melestarikan koleksi negatif kaca agar tetap dalam kondisi baik, maka dilakukan kegiatan konservasi negatif kaca yang dilaksanakan oleh Direktorat Pelestarian Cagar Budaya dan Permuseuman pada tahun anggaran 2012. Kegiatan konservasi telah dilakukan mulai tanggal 23 Juli 2012 dengan target pelaksanaan sebanyak 4000 keping negatif foto dalam bentuk negatif kaca. Terdapat beberapa kode foto dalam negatif kaca selama pengerjaan konservasi yaitu BG, I, Borobudur, OD dan VK. Sampai dengan September 2012 telah di konservasi sebanyak 3399 negatif kaca yang terdiri dari 71 negatif kaca BG I, 222 negatif kaca Borobudur, 2804 negatif kaca OD, dan 302 negatif kaca VK.

\section{B. Proses Perawatan Negatif Kaca:}

1. Pengambilan negatif kaca dari setiap kotak kayu dari dalam lemari rak penyimpanan

2. Pendataan ulang negatif kaca yang terdapat dalam setiap kotak meliputi nomor urut negatif kaca, ukuran negatif kaca dan kotak penyimpannya

3. Meletakkan negatif kaca dalam baki plastik

4. Pembersihan kering dengan menyapukan kuas lunak pada permukaan kaca negatif beti juga dengan kotak kayu penyimpanan negatif

5. Sisi negatif kaca yang ada lapisan emulsi secara hati-hati dan perlahan dibersihkan dengan kuas lunak sampai kotoran atau debu yang melekat pada permukaan kaca tampak bersih;

6. Sisi negatif kaca yang tidak ada lapisan emulsi secara hati-hati dan perlahan dibersihkan dengan kapas yang dibasahi dengan ethanol 70\% dalam aquadest sampai kotoran atau debu yang melekat pada permukaan kaca tampak bersih;

7. Digitalisasi database dengan Scanning negatif kaca. Hasil scanning berdasarkan nomor urut kotak masing-masing dalam satu folder yang sama dalam satu kotaknya. Digitalisasi merupakan pembuatan dokumen secara digital, baik dengan alat pemindai atau scanner maupun dengan pengambilan foto digital. Tujuannya adalah untuk menyimpan gambar yang ada dalam media dan mencegah terjadi sesuatu hal pada benda asli, misalnya: pecah, image emulsion rusak, proses pelapukan, atau akibat dari bencana seperti kebakaran atau banjir. Dengan demikian negara masih memiliki dokumen tersebut dalam bentuk digital. 


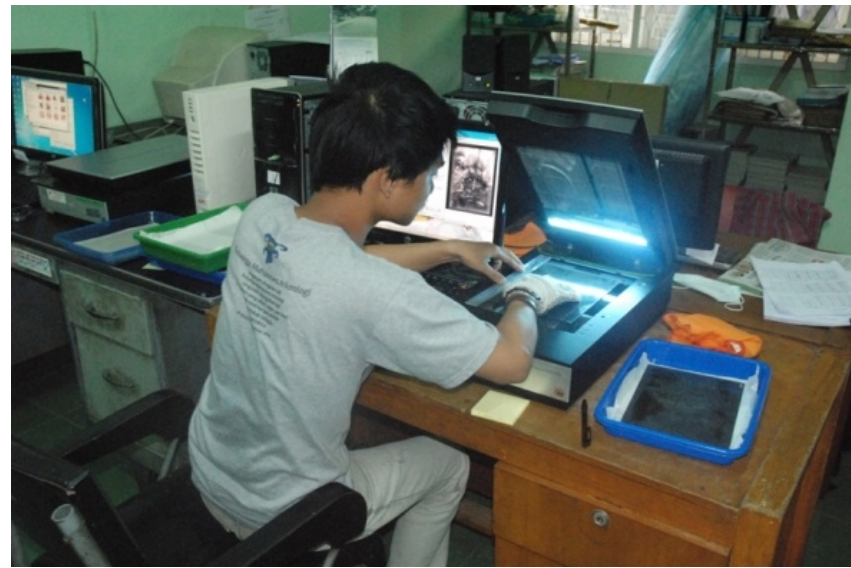

Foto 4. Digitalisasi negatif kaca menggunakan scanner.

8. Mengembalikan negatif kaca ke dalam kotak dan rak penyimpanan

\section{Tenaga Yang Melaksanakan Perawatan Negatif Kaca}

Sehubungan terbatasnya tenaga konservasi di Direktorat Pelestarian Cagar Budaya dan Permuseuman, untuk melaksanakan kegiatan perawatan Negatif Kaca pada Tahun Anggaran 2012, Direktorat Pelestarian Cagar Budaya dan Permuseuman bekerjasama dengan Fakultas Ilmu Budaya, Departemen Arkeologi Universitas Indonesia. Tenaga yang melaksanakan kegiatan perawatan sebanyak 10 orang mahasiswa yang bekerja secara bergantian disesuaikan dengan kegiatan kuliah dari masing-masing mahasiswa. Tenaga Mahasiswa Arkeologi UI sebelum melakukan kegiatan perawatan terlebih dahulu dibekali pengetahuan perawatan negatif kaca oleh tenagatenaga konservasi Direktorat Pelestarian Cagar Budaya dan Permuseuman. Pengetahuan yang diberikan adalah semua hal yang berkaitan tentang proses dan tahapan kegiatan perawatan negatif kaca. Adapun target yang dikerjakan adalah sebanyak 4000 keping negatif kaca, sedangkan jumlah yang dicapai setiap harinya sekitar 2-3 kotak negatif kaca. Seluruh tenaga mampu mengerjakan setiap proses atau tahapan konservasi sehingga tenaga-

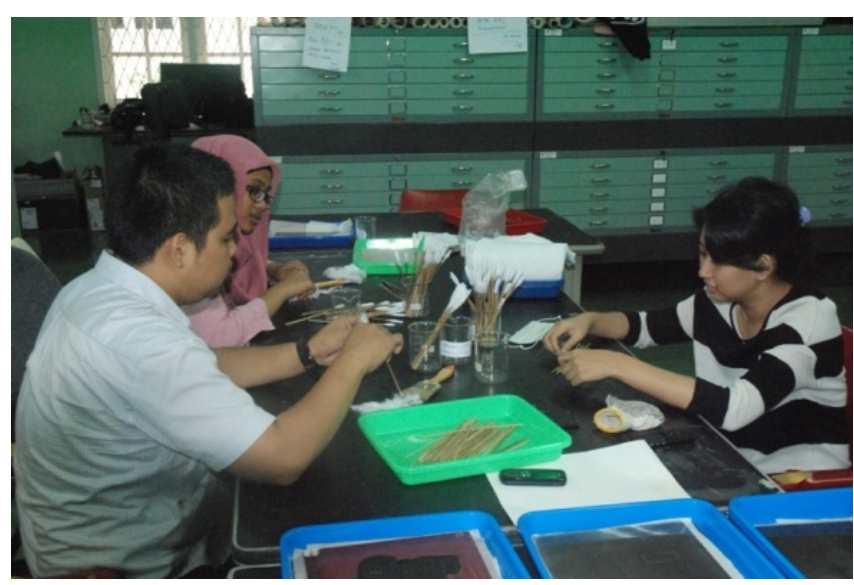

Foto 5. Perawatan negatif kaca.

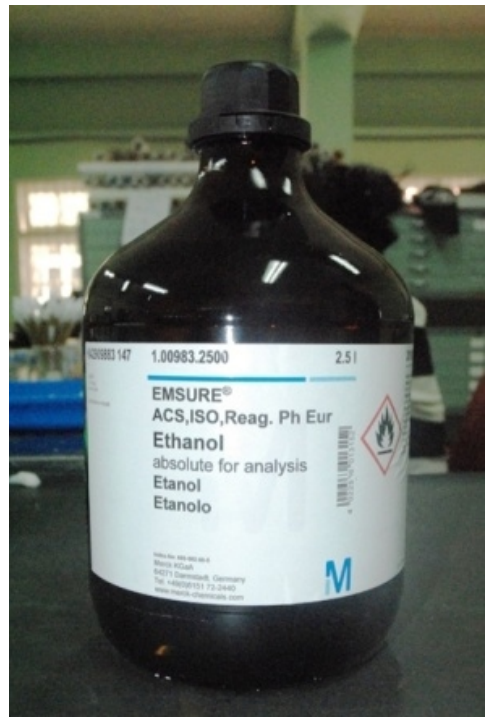

Foto 5. Etanol, merupakan salah satu bahan kimia yang digunakan untuk perawatan negatif kaca.

tenaga tersebut secara bergantian pembersihan atau scanning dan lain sebagainya.

\section{Bahan dan Alat}

Adapun bahan dan alat yang digunakan pada kegiatan konservasi negatif kaca adalah sebagai berikut. Bahan:

\section{Aquadest pa}

2. Etanol $98 \% \mathrm{pa}$

Alat:

1. Kapas

2. Tusuk sate dari bambu

3. Erlenmeyer

4. Beakerglas

5. Baki plastik

6. Sarung tangan

7. Masker

8. Komputer PC

9. Scanner Epson type Perpection V750 PRO

\section{E. Kendala yang dihadapi}

Adapun kendala-kendala yang dihadapi selama kegiatan konservasi negatif kaca antara lain:

1. Terdapat kesulitan dalam mengeluarkan/memasukkan kembali negatif kaca ke dalam kotak kayu, hal ini dikarenakan kondisi kotak kayu yang mengalami proses penyusutan sehingga menjepit keping kaca atau ukuran kotak kayu yang menjadi lebih kecil dari ukuran kaca yang di simpan. Proses penyusutan alami kayu terjadi akibat adanya interaksi kayu terhadap lingkungan baik panas maupun dingin.

2. Keterangan nomor urut yang tertera/ditempel pada kotak harus diperiksa ulang dengan ketersediaan negatif kaca dalam kotak, karena kenyataan banyak nomor yang 
tidak sesuai lagi, misalnya ada nomor urutan tetapi negatif kaca tidak ditemukan dalam kotak atau sebaliknya.

3. Dalam proses pembersihan terdapat negatif kaca yang permukaan kotornya tidak dapat dibersihkan secara sempurna, misalnya masih terlihat seperti jejak air dan permukaannya kesat jika disentuh, hanya kotor debu yang dapat terangkat atau dibersihkan.

4. Dalam proses scanning terdapat hasil scan negatif kaca yang tidak dapat terlihat jelas gambarnya. Selain itu juga tingkat kontras dan kecerahan hasil scan juga kadang berbeda untuk tiap-tiap negatif kaca.

\section{F. Penutup}

Sama seperti koleksi-koleksi kuno lainnya, dokumen kepurbakalaan yang dimiliki Direktorat Peninggalan Purbakala yang meliputi negatif kaca kuno, abklats, peta dan gambar kuno, serta foto positif kuno mengalami proses kerusakan dan menghadapi permasalahan keterawatan seiring perubahan waktu. Jenis

\section{Daftar Pustaka}

Maes, Herman, Photographic Materials, Damage, and Degradation Mechanisms, presentation, NFM Rotterdam, 2008.

-, Digitisation of Photographic Materials, Managing, and Preservation Issues, presentation, NFM Rotterdam, 2008.

--------, Environment, Storage, Facilities, Cold storage, presentation, NFM Rotterdam, 2008.

--------, Packing Materials and Enclosures, presentation, NFM Rotterdam, 2008.

Marpaung, Mananti Amperawan dan Ita Yulita. Report of The Internship on an Intensive Introduction to the Vision and Practice of the Museum, Rotterdam, July 2008.

Direktorat Jenderal Sejarah Dan Purbakala, Departemen Kebudayaan Dan Pariwisata. Koleksi Negatif Kaca Direktorat Peninggalan Purbakala, Jakarta, 2009.

Direktorat Museum, Direktorat Jenderal Sejarah Dan Purbakala, Departemen Kebudayaan Dan Pariwisata. Pedoman Konservasi Koleksi Museum, Jakarta, 2009. kerusakan yang terjadi pada negatif kaca di antaranya adalah pengelupasan lapisan emulsi dari media kaca, goretan pada lapisan emulsi negatif kaca, kaca yang mengalami pecah, debu atau kotoran pada permukaan emulsi, dll.

Permasalahan menyangkut kerusakan pada negatif kaca yang disimpan di Pusat Penyimpanan Dokumen Kepurbakalaan, Direktorat Peninggalan Purbakala, relatif sama. Kerusakan yang terjadi di antaranya adalah tempat penyimpanan yang tidak sesuai, kotak kayu untuk negatif kaca banyak yang mengalami kerusakan akibat faktor usia kayu, ruang yang belum memadai untuk disebut sebagai collection storage system karena tidak ada pengatur temperatur ruang, kontrol kelembapan dan masih ada kebocoran pada atap pada saat hujan. Untuk itu perawatan rutin harus dilakukan secara terjadwal untuk meminimalkan dampak yang ditimbulkan oleh faktor-faktor penyebab kerusakan pada koleksi negatif kaca, baik faktor internal maupun faktor eksternal. 